\title{
Historical Indigenous Land-Use Explains Plant Functional Trait Diversity
}

\author{
Chelsey Geralda Armstrong ${ }^{1}, \underline{\text { Jesse E. D. Miller }}^{2}$, Alex C. McAlvav $^{3}, \underline{\text { Patrick Morgan Ritchie }}^{4}$ and Dana Lepofsky $^{5}$
}

\begin{abstract}
Human land-use legacies have long-term effects on plant community composition and ecosystem function. While ancient and historical land use is known to affect biodiversity patterns, it is unknown whether such legacies affect other plant community properties such as the diversity of functional traits. Functional traits are a critical tool for understanding ecological communities because they give insights into community assembly processes as well as potential species interactions and other ecosystem functions. Here, we present the first systematic study evaluating how plant functional trait distributions and functional diversity are affected by ancient and historical Indigenous forest management in the Pacific Northwest. We compare forest garden ecosystems - managed perennial fruit and nut communities associated exclusively with archaeological village sites - with surrounding periphery conifer forests. We find that forest gardens have substantially greater plant and functional trait diversity than periphery forests even more than 150 years after management ceased. Forests managed by Indigenous peoples in the past now provide diverse resources and habitat for animals and other pollinators and are more rich than naturally forested ecosystems. Although ecological studies rarely incorporate Indigenous land-use legacies, the positive effects of Indigenous land use on contemporary functional and taxonomic diversity that we observe provide some of the strongest evidence yet that Indigenous management practices are tied to ecosystem health and resilience.
\end{abstract}

Key Words: Forest Gardens, Functional Diversity, Land-Use Legacies, Pacific Northwest, Plant Functional Traits

\section{INTRODUCTION}

Contemporary human land use tends to result in biodiversity loss with negative consequences for ecosystem functions and services (Newbold et al. 2015). For example, ongoing land-use changes resulting from urbanization and agricultural development are considered major threats to biodiversity and tend to fulfill shortterm human production needs (Tsiafouli et al. 2015, Beckmann et al. 2019). More recently, however, increasing recognition of Indigenous land-use practices has led to a more nuanced and complex view of how people have affected contemporary ecological communities in more positive ways (Garnett et al. 2018, Levis et al. 2018, Schuster et al. 2019, Fa et al. 2020). For millennia, human land-use and resource management strategies have encompassed a broad range of practices with long-term effects reaching into almost every bioregion of the world (Balée 2013, Rick et al. 2013, Stephens et al. 2019). Research demonstrates that some of these practices have led to an increase in plant species diversity and in nutrient subsidies affecting elements such as phosphorus and nitrogen (Cook-Patton et al. 2014, Trant et al. 2016, Odonne et al. 2019) and can leave unique genetic signatures in extant plant communities (Thompson et al. 2015, Kistler et al. 2018). These land-use and management legacies contrast with the reduced species diversity, habitat loss, and soil depletion often associated with large-scale industrial land-use and other markers associated with the Anthropocene (Sanderman et al. 2017).

While there is growing evidence that some ancient and historical management practices can have long-persisting and positive effects on plant communities, there has been little investigation as to whether these legacies favor plants with particular life histories, or whether they scale up to affect other ecosystem properties (Mayfield et al., 2010, Mouillot et al. 2013). For example, although Indigenous peoples' land-use legacies are well known to affect biodiversity at various scales (e.g., see Cook-
Patton et al. 2014 for alpha diversity, Odonne et al. 2019 for beta diversity), increasingly conservation scientists are concerned not only about the number of species present, but also the diversity of their functional traits (Heilmeier 2019). Plant functional traits are readily measurable characteristics of plant species that can give insights into community assembly processes and ecological interactions (e.g., drought tolerance, nitrogen-fixing capabilities, etc.) (Lavorel 2013, Osborne et al. 2018). While functional traits have been used to study wild ecosystems as well as anthropogenically altered industrialized and agricultural landscapes (e.g., Lohbeck et al. 2018), to our knowledge there has been no previous application of functional diversity metrics to Indigenous peoples' managed landscapes.

While it is widely accepted that before colonial invasions Indigenous societies in the Pacific Northwest of North America did not develop agriculture per se, Indigenous peoples have managed plant species and enhanced terrestrial landscapes in unique and impactful ways (Turner 2014, Anderson 2013). For millennia, Indigenous peoples increased plant productivity and availability through long-distance transplanting, controlled burning, weeding, fertilizing, coppicing, and pruning (to increase flowering, yields of fruit, promoting health and vigor, and to control size) (Lepofsky and Armstrong 2018, McCune et al. 2013, Hoffman et al. 2017). Indigenous forest gardens are one type of historically managed ecosystem that has left imprints on contemporary landscapes in the Pacific Northwest. Forest gardens are ecosystems characterized by perennial fruit and nut tree and shrub species that continue to grow at archaeological village sites (McDonald 2003, Armstrong 2017, Lepofsky et al. 2017) (Fig. 1). Despite the extensive evidence of Indigenous peoples' land use and management practices, we know little about how management legacies like forest gardens influence contemporary ecosystem function and diversity.

\footnotetext{
${ }^{1}$ Indigenous Studies, Simon Fraser University, ${ }^{2}$ Department of Biology, Stanford University, 371 Stanford Mall, Stanford, California 94305 , ${ }^{3}$ Institute of Economic Botany, New York Botanical Garden, ${ }^{4}$ Department of Anthropology, University of British Columbia, ${ }^{5}$ Department of Archaeology, Simon Fraser University
} 
Fig. 1. The Village complex of Dałk Gyilakyaw consists of three discrete villages and is the ancestral home of Gitsm'geelm (Ts'msyen) people. Note the dramatic vegetation change between the forest garden and encroaching conifers ("periphery forests"). Photograph: S. Carroll.

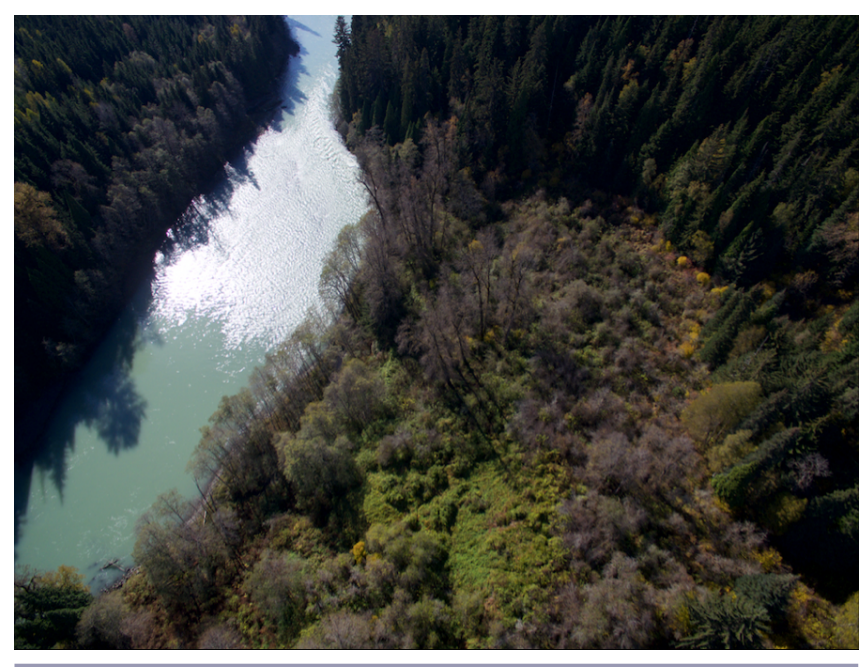

Characterizing the effects of historical land use and management is challenged by our limited ability to accurately reconstruct landuse histories centuries or millennia after such activities ceased, and by the fact that some management practices often mimic natural processes, thereby obscuring such legacy effects (Lepofsky and Armstrong 2018). Forest gardens provide a unique opportunity to analyze functional traits and diversity, given that many of these ecosystems persist at archaeological village sites, despite the fact that over a century has elapsed since people last maintained them. Still, remnant forest gardens on the west coast of Canada (British Columbia) are slowly contracting due to encroachment by conifer trees, which tend to colonize disturbed woodlands in the region (e.g., Deal et al. 2004). Periphery conifer forests at the interface of forest gardens were not managed to the same extent and therefore provide an opportunity to examine how Indigenous peoples' land-use legacies may affect species composition and functional diversity relative to naturally occurring forests. We use plant inventories $(n=46)$ and examine species richness and four functional traits, as well as functional diversity metrics (measures of the range and distribution of functional traits within communities) at four forest gardens and periphery conifer forests at archaeological village complexes in British Columbia (Fig. 2). The selected functional traits-seed mass, shade tolerance, pollination syndrome, and dispersal syndrome - represent axes of life history variation that we expect to be affected by human actions (see Funk et al. 2017 on trait selection), and thus we predict distinct patterns of trait distributions between the forest gardens and periphery forests.

Specifically, we predict that understory species in the remnant forest gardens will have greater functional diversity than those in periphery forests, as well as distinct mean values for several ecologically and ethnobotanically important functional traits. We expect that forest garden sites will contain plants with larger average seed mass since larger seeds are associated with larger fruits, which tend to have economic value for humans. We also predict that periphery forest understory species will be composed of more shade-tolerant species because their canopies are more closed than those in the forest gardens. The open canopy structure in forest gardens may be a result of these areas being cleared of larger conifer trees for gardening (tending, weeding, pruning, etc.), for building, and for defensive viewscapes. We anticipate that a greater proportion of plants in forest gardens will be animalpollinated and animal-dispersed since many of the edible fruit and nut species for humans tend to be insect-pollinated and favored by birds and other large mammals (e.g., bears). In uncovering the specific effects of Indigenous land-use legacies, we anticipate a greater understanding of ecosystem function and productivity. This study provides a unique functional diversity approach that can be used to consider the importance of Indigenous peoples in conservation and decision-making, following global calls to action on this topic (Garnett et al. 2018, Fa et al. 2020).

Fig. 2. Location of Study Sites. Archaeological village complexes in this study: (1) Dałk Gyilakyaw on the Kitsumkalum River, a tributary of the Skeena River; (2) Kitselas Canyon (Gitsaex) on the Skeena River; (3) Say-mahmit in Burrard Inlet; (4) Shxwpópélem on the Harrison River.

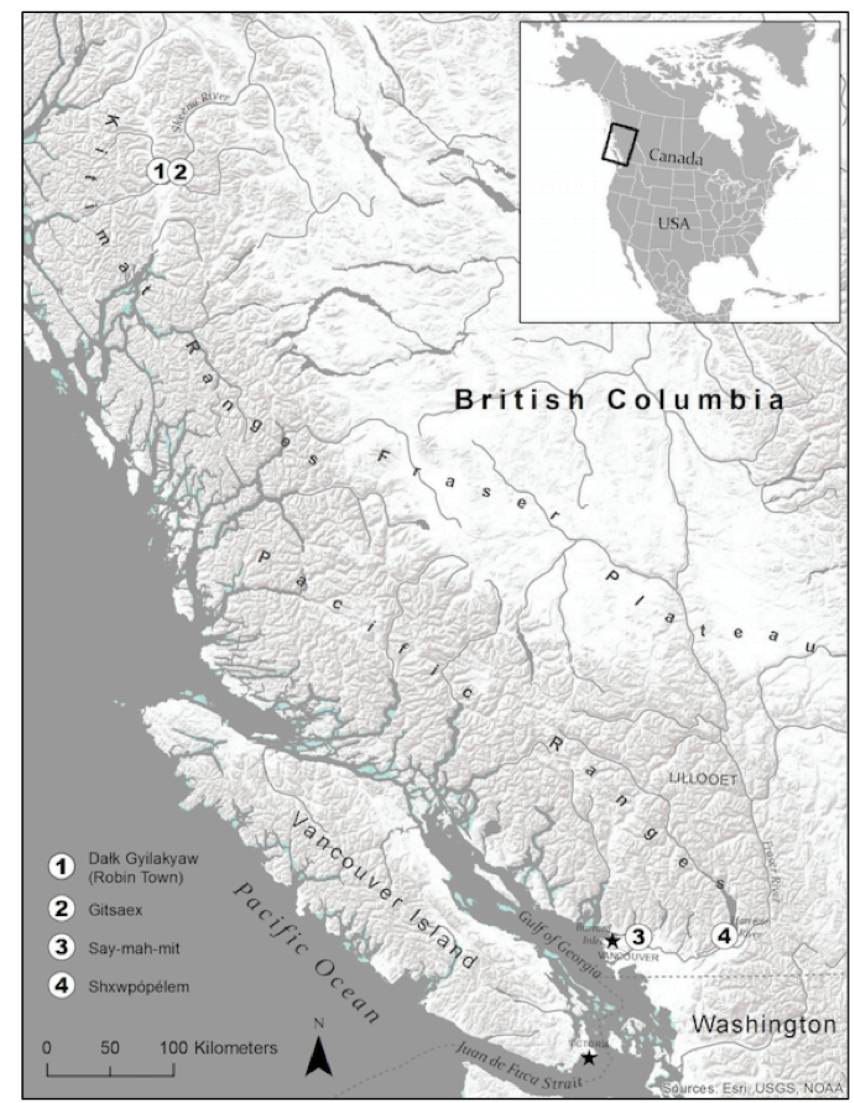




\section{MATERIALS AND METHODS}

\section{Study Sites}

We adopted the term forest gardens to refer to novel ecosystems that have been managed and maintained by Indigenous peoples and thus have no natural analog. Forest gardens in the Pacific Northwest differ from those in the tropics and subtropics in that the latter are generally characterized by an emergent layer or overstory of economically important trees associated with latestage succession plants and mixed cropping swidden systems (e.g., Ford and Nigh 2016). Temperate forest gardens in the Pacific Northwest consist of a canopy layer of mostly small fruit and nut trees, an understory of various berry species, and a forest floor of herbaceous plants traditionally used for food and medicine (Armstrong 2017, Lepofksy et al. 2017).

In order to investigate the functional diversity legacies of forest gardens, we sampled plant communities from four archaeological village complexes in British Columbia, Canada (Fig. 2). A village complex refers to a landscape with two or more adjacent villages consisting of multiple houses (5-20 houses per village). Two Ts'msyen village complexes in northwestern British Columbia (BC) and two Coast Salish complexes in southwestern BC were chosen for their long-term and consistent occupation $>2000$ years), until around the late $1800 \mathrm{~s}$, when people were displaced by settler-colonialism (e.g., people left villages after smallpox epidemics, moved to settler forts and canneries for wage labor, etc.). Three of the village complexes (Dałk Gyilakyaw, Kitselas Canyon, and Shxwpópélem) are situated on major salmon-spawning rivers in transitional ecological zones between Coastal Western Hemlock and the Interior Mountain Hemlock biogeoclimatic zones (Pojar et al. 1987). The fourth village complex, Say-mah-mit, is a shell midden site in the Coastal Douglas-fir and Coastal Western Hemlock biogeoclimatic zones on a marine inlet near the city of Vancouver. The disparate locations of the four archaeological sites in distinct regions of coastal BC offer opportunity to study vegetation patterns across varying regional vegetation types and cultural complexes.

Archaeological village complexes in this study consist of the material legacies of Indigenous societies that created and maintained living structures, fish traps, forest gardens, root gardens, cooking pits, and other features for defense, transport, and food production. Each of the villages in this study has been archaeologically investigated (MacDonald and Inglis 1980, Coupland 1988, Lepofsky et al. 2017, Lyons and Ritchie 2017, Morin et al.2018) and documented ethnographically (Wright 1962, McDonald 2003). For each village complex we compare plant communities in (1) forest gardens directly adjacent to archaeological features and, (2) periphery conifer forests at the margins of villages $(\sim 300+\mathrm{m}$ from closest village features such as house depressions).

\section{Field Sampling Protocol}

We conducted botanical inventories in $5 \times 5 \mathrm{~m}$ plots in both forest gardens and periphery forests. In each plot $(n=46)$, tree species were counted, and percent cover was estimated for shrub (woody species, including small trees under $3 \mathrm{~m}$ height), and herbaceous (non-woody species) layers. Percent coverage was estimated as expression of canopy cover (of the entire plot) for shrubs and ground cover (of the entire plot) for herbaceous plants. We calculated species richness as the number of tree, shrub, and herb species in each plot. At each of the archaeological sites, we selected plots at random and additional plots were sampled until species richness was recorded to redundancy (i.e., no new species recorded). A buffer of roughly $50 \mathrm{~m}$ between forest gardens and periphery forests at each site was used to delineate sampling areas. This resulted in five to nine plots per forest garden and four to five plots per periphery forest being sampled. Forest gardens and periphery forests were ecologically comparable, occurring on similar soil types and topographic positions.

\section{Trait Selection and Database Assembly}

To characterize the functional diversity of understory plant communities, we focused on four traits: seed mass, shade tolerance, pollination syndrome, and dispersal syndrome. We chose these traits because they represent important axes of plant life-history variation and can also have important consequences for ecosystem functioning, while also having relevance to ethnobotanical plant uses (Pérez-Harguindeguy et al. 2013). For example, plants with animal-dispersed seeds may be able to disperse long distances and may also contribute to wild life habitat by providing edible fruits; these plants are also more likely to be eaten by people. We assembled trait data from the TRY database (Kattge et al. 2020), the Fire Effects Information Service (https:// www.feis-crs.org/feis/), and from other studies (Amador et al. 2013, Spasojevic et al. 2014). Traits were collected using standard protocols (Pérez-Harguindeguy et al. 2013). Dry seed mass was standardized to grams per 1000 seeds. For shade tolerance, species were classified as having low, intermediate, or high shade tolerance. Pollination syndrome was characterized for each species as wind-pollinated, insect-pollinated, or self-pollinated. Dispersal syndromes were classified as unassisted, wind-, water-, or animal-dispersed. Our trait database represented $>80 \%$ of total understory plant cover in each plot.

\section{Functional Diversity Metrics}

Functional diversity can provide insight into ecosystem functioning, resilience, productivity (Whittaker 1960), and the processes underpinning community composition (Mouillot et al. 2013). To assess functional diversity, we calculated three functional diversity metrics using the R package FD (Mason et al. 2005). To avoid redundancy given the strong correlations between some functional diversity metrics (Mouchet et al. 2010), we analyzed only three metrics: functional evenness (the evenness of functional trait distribution in niche space; Villéger et al. 2008), functional divergence (the degree of divergence in functional traits within niche space; Villéger et al. 2008), and functional dispersion (the average distance to the abundance-weighted centroid of functional trait values; Laliberté, and Legendre 2010). We omitted functional richness, a functional diversity metric often analyzed alongside functional divergence and functional evenness, as it does not account for dispersion or relative abundances and is somewhat correlated with functional dispersion (Mason et al. 2005).

\section{Statistical Methods}

To characterize community-level functional trait patterns, we used linear mixed models, which have higher power and lower type I error rates (i.e., fewer false positives) than other commonly used trait-environment analysis approaches (Miller et al. 2018). We ran a separate model for each of the four traits we analyzed (See Supplementary Materials). Square-root-transformed species 
Table 1. Indicator species and ethnobotanical significance of forest gardens and periphery forests based on Turner (2014). Indicator species differed significantly between both site types. Key: $\mathbf{X}$, extensive use; $x$, some use; -, use not determined.

\begin{tabular}{|c|c|c|c|c|c|c|c|}
\hline \multirow[t]{2}{*}{ Species } & \multicolumn{5}{|c|}{ Ethnobotanical Significance } & \multicolumn{2}{|c|}{ Indicator Values } \\
\hline & $\begin{array}{c}\begin{array}{c}\text { Edible } \\
\text { (stored) }\end{array} \\
\end{array}$ & Edible & Fuel & Technology & Medicine & Confidence & P-value \\
\hline \multicolumn{8}{|l|}{ Forest Garden } \\
\hline Corylus cornuta (Beaked hazelnut) & $\mathbf{X}$ & $\mathbf{X}$ & $\mathrm{x}$ & $\mathbf{X}$ & $\mathbf{X}$ & 0.97954 & 0.001 \\
\hline Malus fusca (Pacific crabapple) & $\mathbf{X}$ & $\mathbf{X}$ & $\mathrm{x}$ & $\mathrm{x}$ & - & 0.97693 & 0.001 \\
\hline Viburnum edule (Highbush cranberry) & $\mathbf{X}$ & $\mathbf{X}$ & - & $\mathrm{x}$ & $\mathbf{X}$ & 0.91132 & 0.027 \\
\hline Sambucus racemosa (Red elderberry) & $\mathbf{X}$ & $\mathbf{X}$ & - & $\mathrm{x}$ & $\mathrm{x}$ & 1.0000 & 0.029 \\
\hline Maianthemum racemosum (Solomon's plume) & - & $\mathbf{X}$ & - & - & $\mathrm{x}$ & 1.0000 & 0.031 \\
\hline Rosa nutkana (Nootka rose) & $\mathbf{X}$ & $\mathbf{X}$ & - & $\mathrm{x}$ & $\mathbf{X}$ & 0.71933 & 0.034 \\
\hline Cornus sericea (Red osier dogwood) & - & - & - & $\mathbf{X}$ & $\mathbf{X}$ & 1.0000 & 0.04 \\
\hline Rubus spectabilis (Salmonberry) & $\mathbf{X}$ & $\mathbf{X}$ & - & $\mathrm{x}$ & - & 0.7563 & 0.042 \\
\hline Crataegus douglasii (Black hawthorn) & $\mathbf{x}$ & $\mathbf{X}$ & - & $\mathrm{x}$ & $\mathbf{X}$ & 1.0000 & 0.043 \\
\hline Lonicera involucrata (Black twinberry) & - & - & - & $\mathrm{x}$ & $\mathbf{X}$ & 1.0000 & 0.05 \\
\hline \multicolumn{8}{|l|}{ Periphery Forest } \\
\hline Tsuga heterophylla (Western hemlock) & $\mathbf{X}$ & $\mathrm{x}$ & $\mathbf{X}$ & $\mathrm{x}$ & $\mathrm{x}$ & 0.91442 & 0.001 \\
\hline Alnus rubra (Red alder) & - & - & $\mathrm{x}$ & $\mathrm{x}$ & $\mathrm{x}$ & 0.90114 & 0.004 \\
\hline Thuja plicata (Western redcedar) & - & - & $\mathbf{X}$ & $\mathbf{X}$ & $\mathrm{x}$ & 0.88835 & 0.008 \\
\hline Rubus armeniacus (Himalayan blackberry) ${ }^{\dagger}$ & - & $\mathrm{x}$ & - & - & - & 0.93166 & 0.035 \\
\hline Epilobium angustifolium (Fireweed) & - & $\mathrm{x}$ & - & $\mathbf{X}$ & $\mathrm{x}$ & 0.86155 & 0.045 \\
\hline
\end{tabular}

abundance was used as the response variable. Site history (i.e., forest garden or periphery forests), the functional trait, and their interaction were included as fixed effects. Species and site history were included as random effects, and slopes of different species were allowed to vary in response to site history. We evaluated whether traits responded to site history by the significance of the trait-site history interaction term (Miller et al. 2018). We calculated $\mathrm{P}$-values for interaction terms using 4000 bootstrapped simulations per model with the bootMer package, as recommended by Miller et al. (2018). The functional trait analyses included only herbs and shrubs since our goal was to characterize functional traits of the understory community.

We used simpler linear mixed models to test whether species richness and functional diversity metrics responded to site history. In these models, species richness or functional diversity metrics were response variables, site history was the fixed effect, and village was the random effect. We performed all analyses using the lme4 package in $\mathrm{R}$ (Bates et al. 2014). To identify species that are characteristic of different land-use histories, we conducted an indicator species analysis using the $\mathrm{R}$ package indicspecies (De Cáceres and Jansen 2015).

\section{RESULTS}

Plant communities in forest gardens and periphery forests were found to be conspicuously distinct from one another even $>150$ years after people left their villages following colonial-settler invasions. One hundred and nineteen plant taxa were recorded across the forest gardens and periphery forests at our four study sites. Fifteen plant species were strongly associated with either one type of site or the other (i.e., with no cross-over). Across all archaeological village sites, ten plant species were found to be significant indicators of forest gardens $(\mathrm{P}<0.05)$, and these are all ethnobotanically important plants (Table 1; see also Turner 2014). At two village sites, Robintown and Kitselas Canyon, two indicator species-hazelnut (Corylus cornuta) and Pacific crabapple (Malus fusca) - fall outside of their natural geographic range, and both have well documented ethnographic evidence for anthropogenic influence on their distributions (McDonald 2003, Armstrong et al. 2018). It is likely that transplanting was a significant management practice in the establishment of forest gardens (Turner, Armstrong, and Lepofsky unpublished manuscript). The co-occurrence of all ten indicator species has yet to be observed outside of archaeological contexts (e.g., Klinkenberg 2020) and is therefore unlikely to be the result of natural succession. Edible fruits, including hazelnut, Pacific crabapple, highbush cranberry (Viburnum edule), red elderberry (Sambucus racemosa), Solomon's plume (Maianthemum racemosum), nooka rose (Rosa nutkana), salmonberry (Rubus spectabilis), and black hawthorn (Crataegus douglasii) represent $80 \%$ of the forest garden indicator species - all ethnobotanically salient and storable foods (Turner 2014). Five plant species, predominantly conifer trees, are significant $(\mathrm{P}<0.05)$ indicators of the periphery forests, including western hemlock (Tsuga heterophylla) and western redcedar (Thuja plicata) (Table 1). Indicator species in periphery forests are typical dominant species in the study region (Coastal Western Hemlock and the Interior Mountain Hemlock Biogeoclimatic zones, Pojar et al. 1987). The greater richness and diversity of plant foods in forest gardens than in the periphery forests may reflect the fact that Indigenous peoples encouraged some plants close to home for specific properties like edibility and storability.

Forest gardens had significantly higher species richness than the periphery forests ( $\mathrm{P}<0.001$, Fig. 3 ). There was no significant difference in the number of herbaceous species between village forest gardens and periphery sites $(\mathrm{P}=0.81)$; forest gardens contained significantly more shrubs $(\mathrm{P}<0.001)$, while periphery forests contained more tree species $(P=0.02)$. Site history (forest garden or periphery) influenced community functional trait patterns for all four traits we examined. Forest garden plants had larger seeds $(\mathrm{P}=0.003)$, more animal-dispersed species $(\mathrm{P}<$ 0.002), more shade-tolerant species $(\mathrm{P}<0.001$, Fig. 4$)$, and more insect-pollinated species $(\mathrm{P}=0.005)$ than periphery forests. Forest 
Fig. 3. Total Species Richness and Species Richness by Lifeform. Richness is indicated overall between forest gardens and periphery forests (averaged across the four of the study areas) and among the three growth forms (trees, shrubs and herbs).
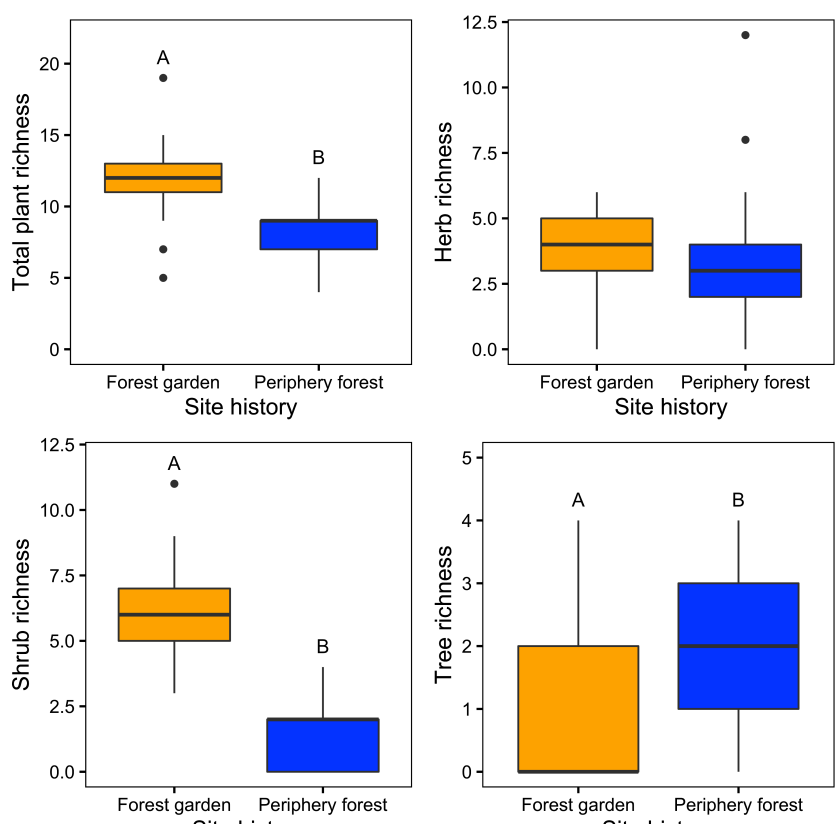

Site history
Fig. 4. Functional Trait Measures between Forest Gardens and Periphery Forests. Comparisons of average seed mass, shade tolerance, pollination syndrome, and dispersal syndrome traits for herbs and shrubs across forest gardens and peripheral forests - all are significantly higher in the forest gardens.
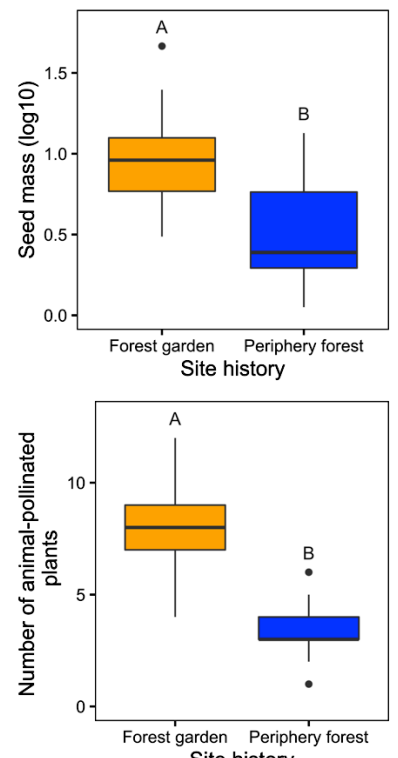

Site history
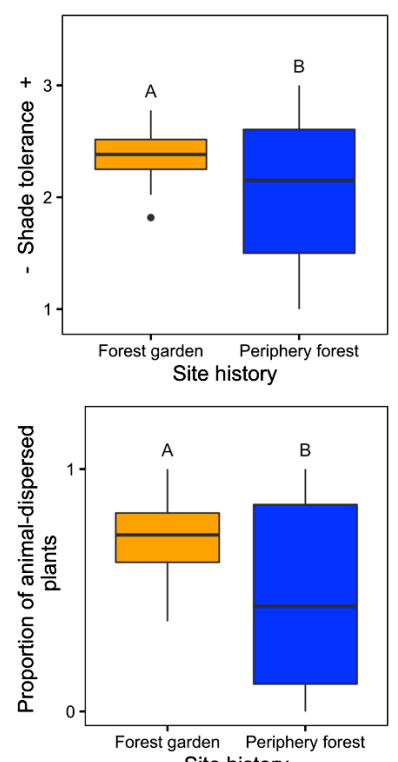

Site history gardens also had higher functional evenness $(\mathrm{P}<0.001)$ and functional dispersion $(\mathrm{P}=0.001)$ than periphery forests, but they differed only marginally in functional divergence $(\mathrm{P}=0.07)$ (Fig. $5)$.

Fig. 5. Functional Diversity Measures between Forest Gardens and Periphery Forests. Comparisons of functional diversity at forest gardens and peripheral forests, functional divergence did not show a significant response to site history $(P=0.07)$.
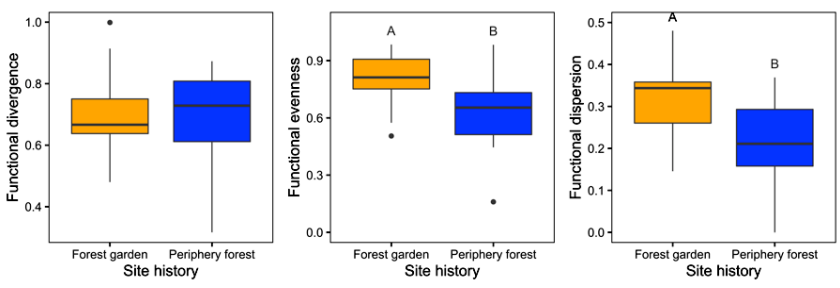

\section{DISCUSSION}

Understanding drivers of plant traits and community diversity and composition has posed a long-standing challenge for ecologists because plant communities are influenced by multiple factors operating at different spatial and temporal scales (Miller et al. 2017, 2018). Human land-use legacies are a potentially important driver of contemporary plant community structure and function that is often rarely considered in ecological studies (in part because historical and ancient activities are often difficult to document). Our findings highlight that historical Indigenous land-use legacies can support long-persisting (e.g., 150+ years) high functional and taxonomic plant diversity relative to less intensively utilized or managed landscapes nearby. Notably, this contrasts with most studies of land-use legacies of human impact which often find negative effects from human influences (e.g., industrial land-use; Newbold et al.2015). The taxonomic diversity of forest gardens in our study region is similar to that in biodiversity studies of Indigenous village sites and forest gardens in other parts of the world, including the Amazonian neotropics (Balée 2013, Heckenberger et al. 2007), eastern Mexico (GómezPompa 1987), and northwestern Belize (Ford and Nigh 2016), where people increased the diversity of desired food plants or overall landscape (beta) diversity (Ross 2011, Odonne et al. 2019). This research builds on an increasing awareness among scientists that biodiverse ecosystems globally have been formed and maintained by Indigenous peoples (Garnett et al. 2018, Fa 2020). There is therefore a greater need to understand the role of Indigenous management practices, including their impacts and effects, and to comprehend the many variables that support the resilience and other functions of managed forest systems.

Since forest gardens have greater functional diversity than periphery forests, they likely provide a suite of ecosystem functions that periphery forests do not (Whittaker 1960). The higher functional evenness in forest gardens may indicate more effective use of locally available resources (Mason et al. 2005), while the less even distribution of functional traits in periphery forests suggests that niche space may be underutilized. This could potentially lead to lower productivity and higher susceptibility to invasion (Mason et al. 2005). Indeed, Himalayan blackberry (Rubus armeniacus), an invasive and non-native species, was an indicator of village periphery sites (Table 1). 
The greater functional evenness observed in forest gardens indicates a greater likelihood of resilience in the face of succession (conifer encroachment). This may help explain the long-term persistence of forest garden ecosystems, even after over a century of disuse (see Petchey et al. 2004). Furthermore, the slow ( 150 years) encroachment of conifers into forest garden openings is notable, especially when compared to the rapid encroachment of conifers into other anthropogenic gaps (Banner and LePage 2008). One hypothesis is that the slow encroachment is due to underground processes (soil formation, mycorrhizal associations, etc.) created by the long-term tending of these ecosystems.

Ironically, the resilience of forest gardens may also be related to the reservation system imposed on Indigenous peoples. Reservations typically account for less than $1 \%$ of Indigenous peoples' territories in British Columbia, but they are often exempted from large-scale industrial logging that otherwise occurs on adjacent lands. All four study sites are on reserves and therefore, typical disturbances common in other parts of the region - erosion, flooding, slope failure from logging, and other linear developments that alter hydrology and vegetation - are not present. Forest gardens growing on reserves remain under Indigenous control and are generally protected (if only passively) from destructive colonial land use. Indigenous agency — often ignored in discussions about resilience - is often a major driver of ecosystem resilience (e.g., Rotarangi and Russell 2009). Understanding the many social and ecological reasons for the resilience of forest gardens would be a worthwhile focus of future research.

The greater abundance of large-seeded fruits in forest gardens compared to periphery forests likely reflects the importance of perennial fruit (e.g., huckleberries [Vaccinium spp.], highbush cranberries, crabapples, saskatoon berries [Amelanchier alnifolia], wild plum [Oemleria cerasiformis]) and nut species for people in the Pacific Northwest. Management of perennial shrubs was an essential and pervasive practice among Indigenous societies in the Pacific Northwest (Turner and Peacock 2005). In habitats with periodic disturbances, large-seeded plants typically have more consistent reproductive success (Venable and Brown 1988), perhaps making them an especially reliable food source near home. However, in addition to the economic viability of larger seed mass for humans (larger edible fruits), management practices that have selected for large-seeded plants may have also conferred long-persisting ecological effects. For example, large seeds tend to be more tolerant of stressful conditions like drought and competition in juvenile life stages (Westoby et al. 2002), which may be another explanatory factor for the persistence of forest gardens and an important feature of future conservation, management, and land-use plans.

The conifer-dominant periphery forests contain fewer shadetolerant species compared to forest gardens, a finding which was not consistent with our hypothesis that closed-canopy conifer forests would favor shade-tolerant species. One explanation for the pattern of more shade-tolerant species in forest gardens is that shade-tolerant species tend to form in more structurally complex communities, with multiple layers of vegetation (e.g., more plant species simultaneously occupying canopy, understory, and shrub layers, and forest floor). There are numerous species in the lower layers of forest gardens (e.g., wild ginger [Asarum caudatum] and wild sarsaparilla [Aralia nudicaulis]) that are therefore sheltered from the sun, despite the lack of a closed upper canopy. Another potential explanation for this pattern is that periphery forests are dominated by species in the emergent and canopy layers but have few species in the understory or shrub layers, perhaps because their environments are too dark for even many shade-tolerant shrubs and herbs. Finally, we recognize that shade-tolerant plants are not necessarily shade obligates, and may grow well in more open environments as well.

The significantly greater number of animal-dispersed and pollinated species in forest gardens relative to the periphery forests is likely a result of people tending and translocating plants near their villages (many animal-dispersed species are consumed by humans). However, after people departed from their villages during settler-colonial invasion ( 1870), forest gardens continued to provide habitat and food for mammals like moose, bear, and deer, and still do today. Ts'msyen Elders have remarked that "old villages" were the best places to hunt. This is unsurprising as forest gardens create patchworks of diversity in otherwise coniferdominated landscapes. Functional traits like animal-dispersal and pollination help us interrogate how forest gardens provided ecosystem services to humans in the past, but also, how they continue to provide ecosystem functions in the present (e.g., animal habitat and food). Furthermore, such traits may help us understand how animals and other pollinators contribute to biologically and functionally diverse ecosystems (e.g., animals frequenting forest gardens are likely dispersing new seeds into them).

Our findings suggest two important lessons for ecologists: (1) the effects of land-use legacies on functional diversity may vary culturally and temporally and (2) ecological studies that do not consider Indigenous peoples' land-use legacies may be missing a major factor contributing to contemporary plant species composition and functional diversity. Indigenous peoples' landuse legacies have produced contemporary plant communities with substantial ecological importance, highlighting their potential conservation value, and these landscapes also have historical, cultural, and economic significance (e.g., Fa et al. 2020). Indigenous land management created a resilient force against some invasive species (e.g., Rubus armeniacus) and its effects persist $150+$ years after management, showing how people may be drivers of relatively stable landscape changes. We encourage archaeologists to treat contemporary plant communities around archaeological sites as potentially part of the cultural landscape (Lepofsky et al. 2020)

The cultural significance of forest gardens for many Indigenous communities today is that they link people to their traditional homelands and represent vestiges of their ancestors. Small-scale and opportunistic berry harvests still occur at Gitseax and Sts'ailes. Legacy plants and associated traditional management, harvesting, and preservation activities also offer descendant communities an important basis for intergenerational knowledge sharing and potential models for food sovereignty initiatives (Nabhan 2014, Wilder et al. 2016). We are only beginning to understand complex eco-human dynamics and as such, future studies should address other plant traits that might have been affected by traditional land-use practices and also consider other lines of evidence (e.g., edaphic and paleoethnobotanical studies, 
etc.). Traits related to resource acquisition and stress tolerance, such as specific leaf area, might be especially important predictors of how plant community composition will shift under global pressures such as climate change (Sayer et al. 2017); further research into such traits could give insight into whether specific traditional management practices can confer plant community resilience in a changing world.

Responses to this article can be read online at: https://www.ecologyandsociety.org/issues/responses. $\mathrm{php} / 12322$

\begin{abstract}
Acknowledgments:
We are grateful to Phil Hahn, Tony Ives, and Marko Spasojevic for providing statistical advice and Nancy J. Turner, Leslie Main Johnson, and Ken Lertzman for providing helpful comments on the manuscript. We acknowledge and thank all the Nations involved in the project: Kitsumkalum, Kitselas, Sts'ailes, and Tsleil-Waututh. We thank Jerram Ritchie, Carly Nabess, Christina Stanley, and Natasha Lyons for help in the field. Funding was provided by National Geographic (\#HJ-085ER-17 awarded to C.G. Armstrong) and by SSHRC (\#31-640024 awarded to D. Lepofsky). We assert that there are no competing interests to this research.
\end{abstract}

\section{Data Availability:}

Data are available on the Figshare Digital Repository: https:// figshare.com/articles/dataset/Data_from_Historical_Indigenous_LandUse_Explains_Plant_Functional_Trait_Diversity/14403926

\section{LITERATURE CITED}

Amador, G. J., Y. Yamada, M. McCurley, and D.L. Hu. 2013. Splash-cup plants accelerate raindrops to disperse seeds. Journal of the Royal Society Interface 10: 20120880 https://doi. org/10.1098/rsif.2012.0880

Anderson, M. K. 2013. Tending the Wild: Native American Knowledge and the Management of California's Natural Resources. University of California Press, Berkeley, CA: https://doi. org/10.1525/9780520933101

Armstrong C. G. 2017. Historical ecology of cultural landscapes in the Pacific Northwest of North America. Doctoral Dissertation, Department of Archaeology, Simon Fraser University, Burnaby, BC.

Armstrong C.G., M. W. Dixon, and N. J. Turner. 2018. Management and Traditional Production of Beaked Hazelnut (k'áp'xw-az', Corylus cornuta; Betulaceae) in British Columbia. Human Ecology 46:547-559. https://doi.org/10.1007/s10745-018-0015$\underline{x}$

Balée, W. 2013. Cultural Forests of the Amazon: A Historical Ecology of People and their Landscapes. University of Alabama Press. Tuscaloosa, AL.

Banner A., and P. LePage. 2008. Long-term recovery of vegetation communities after harvesting in the coastal temperate rainforests of northern British Columbia. Canadian Journal of Forest Research 38:3098-3111. https://doi.org/10.1139/X08-145

Bates, D., M. Maechler, B. Bolker, and S. Walker. 2014. lme4: Linear mixed-effects models using Eigen and S4. $R$ package version 1(7).

Beckmann, M., K. Gerstner, M. Akin-Fajiye, S. Ceaușu, S. Kambach, N. L. Kinlock, H. R. Phillips, W. Verhagen, J. Gurevitch, S. Klotz, and T. Newbold. 2019. Conventional landuse intensification reduces species richness and increases production: A global meta-analysis. Global Change Biology 25: https://doi.org/10.1111/gcb.14606

Cook-Patton, S. C., D. Weller, T. C. Rick, and J. D. Parker. 2014. Ancient experiments: forest biodiversity and soil nutrients enhanced by Native American middens. Landscape Ecology 29:979-987. https://doi.org/10.1007/s10980-014-0033-z

Coupland, G. G. 1988. Prehistoric Cultural Change at Kitselas Canyon (No. 138). Canadian Museum of Civilization, Hull, Que. https://doi.org/10.2307/j.ctv16zsr

De Cáceres, M., and F. Jansen. 2015. Indicspecies: Relationship between species and groups of sites. R package version $1(5)$.

Deal, R. L., P. E. Hennon, E. H. Orlikowska, and D. V. D'Amore. 2004. Stand dynamics of mixed red alder conifer forests of southeast Alaska. Canadian Journal of Forest Research 34:969-980. https://doi.org/10.1139/x04-002

Fa, J. E., J. E. Watson, I. Leiper, P. Potapov, T. D. Evans, N. D. Burgess, Z. Molnár, Á. Fernández-Llamazares, T. Duncan, S. Wang, and B. J. Austin, 2020. Importance of Indigenous Peoples' lands for the conservation of Intact Forest Landscapes. Frontiers in Ecology and the Environment, Early View Online: https://doi. org/10.1002/fee. 2148

FLNRO (British Columbia Ministry of Forests, Lands and Natural Resources Operations). 2011. Vegetation Resources Inventory: Photo Interpretation Procedures. Digital copy available: https://www.for.gov.bc.ca/hfd/library/documents/ bib107005 2011.pdf

Ford, A. and R. Nigh. 2016. The Maya forest garden: eight millennia of sustainable cultivation of the tropical woodlands (Vol. 6). Routledge, London, UK. https://doi.org/10.4324/9781315417936

Funk, J. L., J. E. Larson, G. M. Ames, B. J. Butterfield, J. Cavender-Bares, J. Firn, D. C. Laughlin, A. E. Sutton-Grier, L. Williams, and J. Wright. 2017. Revisiting the holy grail: Using plant functional traits to understand ecological processes. Biological Reviews 92:1156-1173. https://doi.org/10.1111/ brv. 12275

Garnett, S. T., N. D. Burgess, J. E. Fa, Á. Fernández-Llamazares, Z. Molnár, C.J. Robinson, J.E. Watson, K.K. Zander, B. Austin, E.S. Brondizio, E.S. and N.F. Collier. 2018. A spatial overview of the global importance of Indigenous lands for conservation. Nature Sustainability 1:369. https://doi.org/10.1038/s41893-018-0100-6

Gómez-Pompa, A. 1987. On Maya silviculture. Mexican Studies 3:1-17. https://doi.org/10.2307/4617029

Heckenberger, M. J., J. Christian Russell, J. R. Toney, and M. J. Schmidt. 2007. The legacy of cultural landscapes in the Brazilian 
Amazon: implications for biodiversity. Philosophical Transactions of the Royal Society B: Biological Sciences 362:197-208. https:// doi.org/10.1098/rstb.2006.1979

Heilmeier, H., 2019. Functional traits explaining plant responses to past and future climate changes. Flora 254:1-11. https://doi. org/10.1016/j.flora.2019.04.004

Hoffman, K. M., K. P. Lertzman, and B. M. Starzomski. 2017. Ecological legacies of anthropogenic burning in a British Columbia coastal temperate rainforest. Journal of Biogeography 44:2903-2915. https://doi.org/10.1111/jbi.13096

Kattge, J., G. Bönisch, S. Díaz, S. Lavorel, I. C. Prentice, P. Leadley, S. Tautenhahn, G. D. A. Werner, et al. 2020. TRY plant trait database - enhanced coverage and open access. Global Change Biology 26(1):119-188. https://doi.org/10.1111/gcb.14904

Kistler, L., S. Y. Maezumi, J. G. De Souza, N. A. Przelomska, F. M. Costa, O. Smith, H. Loiselle, J. Ramos-Madrigal, N. Wales, E. R. Ribeiro and R. R. Morrison. 2018. Multiproxy evidence highlights a complex evolutionary legacy of maize in South America. Science 362:1309-1313. https://doi.org/10.1126/science. $\underline{\text { aav0207 }}$

Laliberté, E., and P. Legendre. 2010. A distance-based framework for measuring functional diversity from multiple traits. Ecology 91:299-305. https://doi.org/10.1890/08-2244.1

Lavorel, S. 2013. Plant functional effects on ecosystem services. Journal of Ecology 101:4-8. https://doi.org/10.1111/1365-2745.12031

Lepofsky, D. and C. G. Armstrong. 2018. Foraging new ground: documenting ancient resource and environmental management in Canadian Archaeology. Canadian Journal of Archaeology 42:57-73.

Lepofsky, D., C. G. Armstrong, S. Greening, J. Jackley, J. Carpenter, B. Guernsey, D. Mathews, and N. J. Turner. 2017. Historical ecology of cultural keystone places of the Northwest Coast. American Anthropologist 119:448-463. https://doi. org/10.1111/aman.12893

Lepofsky D., C. G. Armstrong, D. Mathews, and S. Greening. 2020. Understanding the past for the future: Plants and First Nations' land use and rights. In Indigenous Peoples' Land Rights and the Roles of Ethnoecology and Ethnobotany: Strategies for Canada's Future. Queens-McGill University Press, Montreal, QB.

Levis, C., B. M. Flores, P. A. Moreira, B. G. Luize, R. P. Alves, J. Franco-Moraes, J. Lins, E. Konings, M. Peña-Claros, F. Bongers, F. R. C. Costa, and C. R. Clement. 2018. How people domesticated Amazonian forests. Frontiers in Ecology and Evolution 5: https://doi.org/10.3389/fevo.2017.00171

Lohbeck, M., L. Winowiecki, E. Aynekulu, C. Okia, and T. G. Vågen. 2018. Trait-based approaches for guiding the restoration of degraded agricultural landscapes in East Africa. Journal of Applied Ecology 55:59-68. https://doi.org/10.1111/1365-2664.13017

Lyons, N., and M. Ritchie. 2017. The Archaeology of camas production and exchange on the Northwest Coast: With evidence from a Sts'ailes (Chehalis) village on the Harrison River, British Columbia. Journal of Ethnobiology 37:346-367. https://doi. org/10.2993/0278-0771-37.2.346
Mason, N. W. H., D. Mouillot, W. G. Lee, and J. B. Wilson. 2005. Functional richness, functional evenness and functional divergence: the primary components of functional diversity. Oikos 111:112-118. https://doi.org/10.1111/j.0030-1299.2005.13886. $\underline{x}$

Mayfield, M. M., S. P. Bonser, J. W. Morgan, I. Aubin, S. McNamara, and P. A. Vesk. 2010. What does species richness tell us about functional trait diversity? Predictions and evidence for responses of species and functional trait diversity to land-use change. Global Ecology and Biogeography 19: 423-431. https://doi. org/10.1111/j.1466-8238.2010.00532.x

MacDonald, G. F. and R. I. Inglis. 1980. An overview of the North Coast prehistory project (1966-1980). BC studies: The British Columbian Quarterly 48:37-63.

McCune, J. L., M. G. Pellatt, and M. Vellend. 2013. Multidisciplinary synthesis of long-term human-ecosystem interactions: A perspective from the Garry oak ecosystem of British Columbia. Biological Conservation 166:293-300. https:// doi.org/10.1016/j.biocon.2013.08.004

McDonald, J. A. 2003. People of the Robin: The Tsimshian of Kitsumkalum: a Resource Book for the Kitsumkalum Education Committee and the Coast Mountain School District 82. CCI Press, Terrace, BC.

Miller, J. E. D., A. R. Ives, S. P. Harrison, and E. I. Damschen. 2017. Early- and late-flowering guilds respond differently to landscape spatial structure. Journal of Ecology 106:1033-1045. https://doi.org/10.1111/1365-2745.12849

Miller, J. E. D., A. Ives, and E. Damschen. 2018. Functional traits and community composition: a comparison among communityweighted means, weighted correlations, and multilevel models. Methods in Ecology and Evolution 10:415-425. https://doi. org/10.1101/183442

Morin, J., D. Lepofsky, M. Ritchie, M. Porčić, and K. Edinborough. 2018. Assessing continuity in the ancestral territory of the Tsleil-Waututh-Coast Salish, southwest British Columbia, Canada. Journal of Anthropological Archaeology 51:77-87. https://doi.org/10.1016/j.jaa.2018.04.004

Mouchet, M. A., S. Villéger, N. W. H. Mason, and D. Mouillot. 2010. Functional diversity measures: an overview of their redundancy and their ability to discriminate community assembly rules. Functional Ecology 24:867-876. https://doi.org/10.1111/ j.1365-2435.2010.01695.x

Mouillot, D., N. A. Graham, S. Villéger, N. W. Mason, and D. R. Bellwood. 2013. A functional approach reveals community response to disturbances. Trends in Ecology and Evolution 28:167-177. https://doi.org/10.1016/j.tree.2012.10.004

Nabhan, G. P. 2014. Food security, biodiversity and human health: ethnobiology as a predictive science. Journal of Ethnobiology 34:7-12. https://doi.org/10.2993/0278-0771-34.1.7

Newbold, T., L. N. Hudson, S. L. Hill, S. Contu, I. Lysenko, R. A. Senior, L. Börger, D. J. Bennett, A. Choimes, B. Collen, and J. Day. 2015. Global effects of land use on local terrestrial biodiversity. Nature 520:45-50. https://doi.org/10.1038/nature14324 
Odonne, G., M. van den Bel, M. Burst, O. Brunaux, M. Bruno, E. Dambrine, et al. 2019. Long-term influence of early human occupations on current forests of the Guiana Shield. Ecology 100: e02806. https://doi.org/10.1002/ecy.2806

Osborne, C. P., T. Charles-Dominique, N. Stevens, W. J. Bond, G. Midgley, C. E. Lehmann. 2018. Human impacts in African savannas are mediated by plant functional traits. New Phytologist 220:10-24. https://doi.org/10.1111/nph.15236

Pérez-Harguindeguy N., S. Díaz, E. Garnier, S. Lavorel, H. Poorter, P. Jaureguiberry, M. S. Bret-Harte, W. K. Cornwell, J. M. Craine, D. E. Gurvich, C. Urcelay, E. J. Veneklaas, P. B. Reich, L. Poorter, I. J. Wright, P. Ray, L. Enrico, J. G. Pausas, A. C. de Vos, N. Buchmann, G. Funes, F. Quétier, J. G. Hodgson, K. Thompson, H. D. Morgan, H. ter Steege, M. G. A. van der Heijden, L. Sack, B. Blonder, P. Poschlod, M. V. Vaieretti, G. Conti, A. C. Staver, S. Aquino, and J. H. C.Cornelissen. 2013. New handbook for standardised measurement of plant functional traits worldwide. Australian Journal of Botany 61:167-234. https://doi.org/10.1071/BT12225

Petchey, O. L., A. Hector, K. J. Gaston. 2004. How do different measures of functional diversity perform? Ecology 85:847-857. https://doi.org/10.1890/03-0226

Pojar, J., K. Klinka, and D. V. Meidinger. 1987. Biogeoclimatic ecosystem classification in British Columbia. Forest Ecology Management 22:119-154 https://doi.org/10.1016/0378-1127(87) 90100-9

Rick, T. C., P. V. Kirch, J. M. Erlandson, and S. M. Fitzpatrick. 2013. Archaeology, deep history, and the human transformation of island ecosystems. Anthropocene 4:33-45. https://doi. org/10.1016/j.ancene.2013.08.002

Ross, N. J. 2011. Modern tree species composition reflects ancient Maya "forest gardens" in Northwest Belize. Ecological Applications 21(1): 75-84. https://doi.org/10.1890/09-0662.1

Rotarangi, S. and D. Russell. 2009. Social-ecological resilience thinking: Can Indigenous culture guide environmental management. Journal of the Royal Society of New Zealand 39 (4):209-2013. https://doi.org/10.1080/03014220909510582

Sanderman, J., T. Hengl, and G. J. Fiske. 2017. Soil carbon debt of 12,000 years of human land use. Proceedings of the National Academy of Science U.S.A. 114:9575-9580. https://doi. org/10.1073/pnas.1706103114

Sayer, E. J., A. E. Oliver, J. D. Fridley, A. P. Askew, R. T. Mills, and J. P. Grime. 2017. Links between soil microbial communities and plant traits in a species-rich grassland under long-term climate change. Ecology and Evolution 7:855-862. https://doi. org/10.1002/ece 3.2700

Schuster, R., R. R. Germain, J. R. Bennett, N. J. Reo and P. Arcese. 2019. Vertebrate biodiversity on indigenous-managed lands in Australia, Brazil, and Canada equals that in protected areas. Environmental Science \& Policy 101:1-6. https://doi.org/10.1016/ j.envsci.2019.07.002

Spasojevic, M., J. Grace, S. Harrison,and E. Damschen. 2014. Functional diversity supports the physiological tolerance hypothesis for plant species richness along climatic gradients.
Journal of Ecology 102(2):447-455. https://doi.org/10.1111/1365$-2745.12204$

Stephens, L., D. Fuller, N. Boivin, T. Rick, N. Gauthier, A. Kay, et al. 2019. Archaeological assessment reveal's Earth's early transformation through land use. Science 365:897-902. https:// doi.org/10.1126/science.aax1192

Thompson, K. M., T. M. Culley, A. M. Zumberger, and D. L. Lentz. 2015. Genetic variation and structure in the neotropical tree, Manilkara zapota (L) P. Royen (Sapotaceae) used by the ancient Maya. Tree Genetics and Genomes 11:1-13. https://doi. org/10.1007/s11295-015-0867-9

Trant, A. J., W. Nijland, K. M. Hoffman, D. L. Mathews, D. McLaren, D., T. A. Nelson, and B. M. 2016. Intertidal resource use over millennia enhances forest productivity. Nature Communications 7:12491. https://doi.org/10.1038/ncomms12491

Tsiafouli, M. A., E. Thébault, S. P. Sgardelis, P. C. De Ruiter, W. H. Van Der Putten, K. Birkhofer, L. Hemerik, F. T. De Vries, R. D. Bardgett, M. V. Brady, and L. Bjornlund. 2015. Intensive agriculture reduces soil biodiversity across Europe. Global Change Biology 21:973-985. https://doi.org/10.1111/gcb.12752

Turner, N. J. 2014. Ancient Pathways, Ancestral Knowledge: Ethnobotany and Ecological Wisdom of Indigenous Peoples of Northwestern North America. McGill-Queen's Press, McGill, Quebec.

Turner, N. J. and S. Peacock. 2005. Solving the perennial paradox: ethnobotanical evidence for plant resource management on the Northwest Coast. In D. Deur and N. J. Turner, editors Keeping It living: Traditions of Plant Use and Cultivation on the Northwestern Coast of North America. 101-150. UBC Press, Vancouver, BC.

Venable, D. L., and J. S. Brown. 1988. The selective interactions of dispersal, dormancy, and seed size as adaptations for reducing risk in variable environments. The American Naturalist 131:360-384. https://doi.org/10.1086/284795

Villéger, S., N. W. Mason, and D. Mouillot. 2008. New multidimensional functional diversity indices for a multifaceted framework in functional ecology. Ecology 89:2290-2301. https:// doi.org/10.1890/07-1206.1

Westoby, M., D. S. Falster, A. T. Moles, P. A. Vesk, and I. J. Wright. 2002. Plant ecological strategies: some leading dimensions of variation between species. Annual Review of Ecology, Evolution, and Systematics 33:125-159. https://doi.org/10.1146/annurev. ecolsys.33.010802.150452

Whittaker, R. 1960. Vegetation of the Siskiyou Mountains, Oregon and California. Ecological Monographs 30:279-338. https://doi.org/10.2307/1943563

Wilder, B. T., C. O'meara, L. Monti and G. P. Nabhan. 2016. The importance of indigenous knowledge in curbing the loss of language and biodiversity. BioScience 66:499-509. https://doi. org/10.1093/biosci/biw026

Wright, W. 1962. Men of Medeek. Northern Sentinel Press, Kitimat, BC. 